\title{
Perbedaan Kemampuan Kelincahan Gerak Antara Peserta Kegiatan Ekstrakurikuler Futsal dan Bolabasket di Sekolah Menengah Atas
}

\author{
Eki Catur Arviansyah*, Siti Nurrochmah \\ Universitas Negeri Malang, Jl. Semarang No. 5 Malang, Jawa Timur, Indonesia \\ *Penulis korespondensi, Surel: ekicatur20@gmail.com
}

Paper received: 3-5-2021; revised: 24-5-2021; accepted: 28-5-2021

\begin{abstract}
Abstrak
Kelincahan gerak merupakan salah satu faktor penting dalam futsal dan bolabasket. Tujuan dari penelitian ini adalah untuk memperoleh informasi ada tidaknya perbedaan yang signifikan kemampuan kelincahan gerak antara peserta kegiatan ekstrakurikuler futsal dan bolabasket SMAN 4 Malang. Rancangan penelitian ini adalah non eksperimental bentuk survei, menurut tujuan penelitiannya termasuk jenis penelitian kausal komparatif dengan jumlah sampel 71 peserta. Berdasarkan hasil penelitian, menunjukkan adanya perbedaan yang signifikan. Perbedaan tersebut dipengaruhi oleh beberapa faktor internal dan faktor eksternal. Sehingga, dapat disimpulkan ada perbedaan yang signifikan kemampuan kelincahan gerak antara peserta kegiatan ekstrakurikuler futsal dan bolabasket di SMAN 4 Malang.
\end{abstract}

Kata kunci: kelincahan gerak; ekstrakurikuler; futsal; bolabasket

\section{Pendahuluan}

Dalam dunia pendidikan saat ini terdapat beberapa aspek pembelajaran yang harus dikuasai oleh peserta didik di setiap mata pelajaran yang ada, diantaranya adalah aspek kognitif, aspek afektif, dan aspek psikomotor. Dalam pembelajaran Pendidikan Jasmani dan Kesehatan agar siswa mampu menguasai beberapa keterampilan dan/atau kemampuan gerak yang baik, pemerintah melalui SK Menteri tahun 2014 tentang pelaksanaan kegiatan ekstrakurikuler, maka sekolah diwajibkan untuk menyelenggarakan kegiatan ekstrakurikuler tersebut. Untuk menindaklanjuti SK Menteri tahun 2014 tersebut, maka SMAN 4 Malang juga telah menyelenggarakan kegiatan ekstrakurikuler. Kegiatan ekstrakurikuler adalah kegiatan kurikuler yang dilakukan oleh peserta didik sesuai bakat dan minatnya masing-masing di luar jam belajar di sekolah, di bawah bimbingan dan pengawasan satuan pendidikan. Diantara sajian kegiatan ekstrakurikuler di SMAN 4 Malang, penulis tertarik mengkaji jenis kegiatan olahraga futsal dan bolabasket.

Menurut Arthawan (2016) futsal adalah sebuah permainan beregu yang mirip dengan sepakbola akan tetapi dimainkan oleh lima pemain setiap tim termasuk seorang penjaga gawang yang dimainkan dengan lapangan, gawang dan bola yang berukuran lebih kecil dari sepakbola. Sedangkan menurut Amiq (2014) "futsal adalah permainan yang sangat cepat dan dinamis. Dari segi lapangan yang relatif kecil, hampir tidak ada ruangan untuk membuat kesalahan". Jadi, menurut beberapa pendapat di atas dapat disimpulkan bahwa pengertian futsal adalah sebuah permainan dalam ruangan yang relatif kecil yang dimainkan oleh kedua regu dengan masing-masing regu terdiri dari lima pemain secara cepat dan dinamis. Bolabasket adalah olahraga permainan yang dimainkan oleh 2 tim dengan jumlah pemain masing-masing tim sebanyak 5 orang, sebagian besar teknik dasarnya dimainkan dengan tangan dan mempunyai tujuan memasukkan bola sebanyak mungkin ke keranjang lawan, serta 
menahan lawan agar tidak bisa memasukkan\ bola ke keranjang tim sendiri dengan cara melempar tangkap (passing), menggiring (dribbling), dan menembak (shooting). Pelatih kegiatan ekstrakurikuler futsal dan bolabasket di SMAN 4 Malang selama ini melakukan latihan secara sistematis dan kontinyu. Setiap kali latihan, kecenderungan hanya fokus pada latihan teknik saja, aspek fisik, taktik, dan mental kurang mendapat perhatian dari para pelatih.

Kondisi fisik merupakan salah satu aspek yang penting untuk mencapai prestasi. Hal ini sesuai dengan pernyataan Ruslan (2011) yang menyatakan bahwa mencapai prestasi yang maksimal membutuhkan kondisi fisik yang baik adalah salah satu faktor yang menentukan dalam mencapai suatu prestasi olahraga. Selain itu, kelincahan juga merupakan salah satu faktor penting dalam permainan futsal dan bolabasket. Kelincahan adalah suatu komponen fisik yang harus dimiliki oleh seorang atlet basket, semakin lincah seorang atlet basket akan semakin bagus dan dapat menunjang prestasi seorang atlet basket (Hidayah \& Wirawan, 2019). Sedangkan di bidang futsal, kelincahan adalah komponen yang sangat penting dari keduanya, futsal dan sepakbola dan itu mewakili karakteristik yang umum (Milanović. et al, 2011. Di sisi lain, penelitian yang telah dilakukan oleh Qorby Haqqul Adam (2015) menyatakan bahwa kesimpulan dari kedelapan faktor biomotor dan psikomotor yang diteliti dan mendukung keterampilan bermain futsal berturut-turut adalah (1) Kelincahan dengan nilai koefisien regresi sebesar 0.318, (2) Daya tahan kardiovaskuler dengan nilai koefisien regresi sebesar 0.304, (3) Keseimbangan dengan nilai koefisien regresi sebesar 0.231, (4) Kecepatan gerak dengan nilai koefisien regresi sebesar 0.190, (5) Fleksibilitas punggung dengan nilai koefisien regresi sebesar 0.178, (6) Power otot tungkai dengan nilai koefisien regresi sebesar 0.176 , (7) Waktu reaksi dengan nilai koefisien regresi sebesar 0.171, (8) Koordinasi mata-kaki dengan nilai koefisien regresi sebesar 0.170 .

Kelincahan merupakan salah satu faktor penting dalam permainan futsal dan bolabasket, karena dalam permainan futsal dan bolabasket pemain dituntut untuk cepat melakukan gerakan sekaligus mengubah arah pada saat melakukan pola penyerangan, pertahanan, maupun transisi di lapangan yang berukuran kecil dan dengan tempo permainan yang relatif cepat. Proses latihan kondisi fisik yang dilakukan secara cermat dan berulangulang dengan kian meningkat beban latihannya memungkinkan kesegaran jasmani seseorang kian terampil, kuat dan efisien gerakannya (Ruslan, 2011). Hal ini berarti bahwa untuk dapat memiliki kemampuan kelincahan yang bagus sehingga dapat bermain futsal dan bolabasket dengan mahir seorang pemain tentu harus berlatih dengan baik secara rutin dan berkelanjutan. Oleh karena itu, setiap pelatih penting untuk mengetahui dan mengontrol perkembangan para pemainnya demi tercapainya prestasi yang lebih baik dalam tim tersebut sehingga dapat mengharumkan almamater sekolahnya.

Mengacu pada studi pendahuluan melalui wawancara dengan pelatih kegiatan ekstrakurikuler futsal SMAN 4 Malang Rendy W. Pamungkas, S.Pd., Gr., dan pelatih kegiatan ekstrakurikuler bolabasket SMAN 4 Malang Drs. Wagiono pada tanggal 3 Mei 2019 tentang keadaan kegiatan ekstrakurikulernya dan kemampuan kondisi fisik para peserta kegiatannya, para pelatih tersebut menjelaskan bahwa jadwal latihan masing-masing kegiatan ekstrakurikuler tersebut dilakukan sebanyak dua kali dalam satu minggu. Kegiatan ekstrakurikuler futsal dilaksanakan pada hari Rabu dan Jumat, sedangkan kegiatan ekstrakurikuler bolabasket dilaksanakan pada hari Sabtu dan Minggu. Kedua kegiatan ekstrakurikuler tersebut memiliki durasi latihan selama dua jam, dimulai pada pukul 15.30 WIB hingga pukul 17.30 WIB. Para pelatih menyatakan bahwa peserta dari kedua kegiatan 
ekstrakurikuler tersebut kurang memiliki semangat dalam berlatih sehingga masih minim prestasi, setiap kali mengikuti sebuah kejuaraan sering kali harus menerima kekalahan dari tim sekolah lain.

Pada saat ditanya tentang program latihan yang diberikan, para pelatih menjelaskan bahwa jarang dilakukan program latihan kondisi fisik, khususnya kelincahan. Kecenderungan latihan dilakukan hanya pada aspek teknik saja. Para pelatih juga tidak pernah melakukan tes kondisi fisik kepada para peserta kegiatan ekstrakurikulernya masing-masing, sehingga tidak mempunyai acuan atau bukti nyata untuk mengetahui kemampuan kondisi fisik para peserta kegiatannya, terutama pada aspek kelincahan gerak. Padahal, kemampuan kondisi fisik merupakan faktor terpenting untuk bisa meraih prestasi.

Berdasar pada hasil angket analisis kebutuhan kegiatan ekstrakurikuler yang dibagikan kepada para peserta kegiatan ekstrakurikuler futsal dan bolabasket SMAN 4 Malang, dapat ditemukan hasil sebagai berikut. Hasil dari peserta kegiatan ekstrakurikuler futsal SMAN 4 Malang dapat disimpulkan bahwa: (1) pelatih kegiatan ekstrakurikuler futsal memberi arahan dari yang mudah ke sulit dalam program latihannya, (2) pelatih kegiatan ekstrakurikuler futsal jarang memberikan tambahan latihan fisik dalam program latihannya (3) banyak peserta kegiatan ekstrakurikuler yang berlatih di luar kegiatan ekstrakurikuler di sekolah, (4) pelatih di luar kegiatan ekstrakurikuler tersebut memberi tambahan latihan fisik. Sedangkan, hasil dari peserta kegiatan ekstrakurikuler bolabasket SMAN 4 Malang dapat disimpulkan bahwa: (1) pelatih kegiatan ekstrakurikuler bolabasket memberi arahan dari yang mudah ke sulit dalam program latihannya, (2) pelatih kegiatan ekstrakurikuler bolabasket jarang memberikan tambahan latihan fisik dalam program latihannya (3) kebanyakan peserta kegiatan ekstrakurikuler bolabasket hanya berlatih pada kegiatan ekstrakurikuler di sekolah saja, (4) tidak adanya tambahan latihan fisik yang dilakukan oleh peserta kegiatan ekstrakurikuler bolabasket.

Berdasarkan latar belakang yang telah dipaparkan di atas dan mengingat pentingnya kemampuan kondisi fisik dalam meraih prestasi, maka penulis ingin mengetahui perbedaan kemampuan kondisi fisik dari kedua peserta kegiatan ekstrakurikuler tersebut, khususnya pada unsur kelincahan gerak. Diharapkan, dengan melakukan tes kelincahan gerak dapat diketahui kemampuan kondisi fisik kelincahan gerak peserta kegiatan ekstrakurikuler futsal dan bolabasket SMAN 4 Malang sebagai acuan para pelatih dan peserta kegiatannya untuk lebih mempersiapkan tim agar dapat berprestasi. Adanya perbedaan kondisi fisik kemampuan kelincahan antar peserta kegiatan ekstrakurikuler ini juga sesuai dengan penelitian Hidayah \& Wirawan (2019) yang berjudul Perbandingan Kondisi Fisik Ekstrakurikuler Bola Basket Putra Di SMAN Pacet Kabupaten Mojokerto dan SMAN 1 Kota Mojokerto Ditinjau Dari Prestasi Yang Diraih. Oleh karena itu, penulis tertarik untuk melakukan penelitian dengan judul "Perbedaan Kemampuan Kelincahan Gerak Antara Peserta Kegiatan Ekstrakurikuler Futsal dan Bolabasket SMAN 4 Malang". Tujuan penelitian ini adalah untuk mengkaji dan memperoleh informasi ada tidaknya perbedaan yang signifikan kemampuan kelincahan gerak antara peserta kegiatan ekstrakurikuler futsal dengan peserta kegiatan ekstrakurikuler bolabasket SMAN 4 Malang.

\section{Metode}

Ditinjau dari sifat permasalahannya, maka penelitian ini menggunakan rancangan non eksperimental bentuk survei, sedangkan ditinjau dari tujuan penelitian yang tercantum pada bab I, maka penelitian ini termasuk jenis penelitian kausal komparatif. Kausal komparatif yaitu 
penelitian yang dilakukan dengan tujuan untuk membandingkan atau membedakan sampel yang satu dengan sampel yang lain (Suliyanto, 2014). Penelitian ini bertujuan hanya untuk mendapatkan kondisi apa adanya dan membedakan variabel yang diteliti antara kedua ekstrakurikuler. Variabel yang diteliti berupa variabel terikat dan variabel bebas. Variabel terikat berupa kondisi fisik kemampuan kelincahan gerak peserta kegiatan ekstrakurikuler futsal dan bolabasket SMAN 4 Malang. Sedangkan, variabel bebas berupa jenis kegiatan ekstrakurikuler olahraga permainan yaitu ekstrakurikuler futsal dan bolabasket SMAN 4 Malang.

Populasi pada penelitian ini merupakan seluruh peserta kegiatan ekstrakurikuler futsal putra dan bolabasket putra SMAN 4 Malang. Jumlah populasi peserta kegiatan ekstrakurikuler futsal putra SMAN 4 Malang sebanyak 39 peserta, sedangkan jumlah populasi peserta kegiatan ekstrakurikuler bolabasket putra SMAN 4 Malang sebanyak 40 peserta. Sehingga, total populasi dalam penelitian ini sebanyak 79 peserta. Teknik pengambilan sampel dalam penelitian ini menggunakan teknik systematic purposive proportional random sampling dengan porsi $90 \%$. Hal ini berarti untuk sampel peserta kegiatan ekstrakurikuler futsal putra SMAN 4 Malang terambil 35 peserta, sedangkan untuk sampel peserta kegiatan ekstrakurikuler bolabasket putra SMAN 4 Malang terambil 36 peserta. Sehingga total sampel dalam penelitian ini berjumlah 71 peserta.

Instrumen penelitian adalah alat-alat yang digunakan untuk memperoleh atau mengumpulkan data dalam rangka memecahkan masalah penelitian atau mencapai tujuan penelitian (Winarno, 2013). Penelitian ini menggunakan dua macam instrumen, yaitu instrumen tes dan non tes. Instrumen tes yang digunakan adalah tes kelincahan gerak berupa Illinois Agility Run Test, karena menurut Homoud (2015) tes Illinois digunakan untuk menentukan kemampuan mempercepat, memperlambat, perubahan arah yang berbeda, dan berlari pada sudut yang berbeda. Sedangkan instrumen non tes berupa pedoman observasi (pengamatan) yaitu mengamati unjuk kerja pada saat tes kondisi fisik kemampuan kelincahan gerak menggunakan Illinois Agility Run Test.

Teknik pengumpulan data dalam penelitian ini menggunakan teknik pengukuran bentuk tes, yaitu tes kondisi fisik berupa tes kelincahan gerak. Tes merupakan salah satu instrumen yang dapat digunakan sebagai dasar dalam memberikan penilaian, tes sebagai alat untuk memperoleh informasi tentang karakteristik peserta didik atau sifat suatu objek (Nurrochmah, 2016). Selain teknik pengukuran, dalam penelitian ini juga menggunakan teknik observasi yang dilengkapi dengan pedoman observasi. Langkah-langkah yang dilakukan dalam tahap pengumpulan data yaitu tahap persiapan, tahap pelaksanaan, dan tahap pelaporan hasil penelitian.

Berdasarkan tujuan penelitian dan pertimbangan jenis data yang diperoleh berupa data rasio, maka teknik analisis data yang digunakan untuk mengungkap tentang perbedaan kemampuan kelincahan gerak antara peserta kegiatan ekstrakurikuler futsal dan bolabasket SMAN 4 Malang adalah teknik statistika parametrik berupa uji $\mathrm{T}$ sampel bebas menurut (Siregar, 2015). Teknik analisis data tersebut membutuhkan uji prasyarat yang meliputi uji normalitas dan uji homogenitas. Uji normalitas menggunakan uji Kolmogorov-Smirnov menurut Hamid, dkk (2017). Sedangkan, uji homogenitas menggunakan uji $F$ menurut Budiwanto (2017). 


\section{Hasil dan Pembahasan}

\subsection{Hasil}

Data hasil tes kemampuan kelincahan gerak menggunakan Illinois Agility Run Test yang akan dianalisis adalah skor terbaik dari masing-masing peserta kegiatan ekstrakurikuler futsal dan bolabasket SMAN 4 Malang yang sudah melaksanakan Illinois Agility Run Test. Hasil penelitian yang disajikan dalam bentuk tabel meliputi: rata-rata (mean), simpangan baku (SD), skor maksimum, dan skor minimum. Pada tabel berikut ini akan disajikan hasil tes kelincahan gerak peserta kegiatan ekstrakurikuler futsal dan bolabasket SMAN 4 Malang yang telah diperoleh peneliti.

Tabel 1. Deskripsi Data Hasil Tes Kelincahan Gerak Peserta Kegiatan Ekstrakurikuler Futsal dan Bolabasket SMAN 4 Malang

\begin{tabular}{ccc}
\hline Nama Ekstrakurikuler & Jenis Statistik & Kelincahan Gerak \\
\hline Ekstrakurikuler Futsal & $\mathrm{n}$ & 35 \\
& Mean & 18,56 detik \\
& SD & 0,86 detik \\
& Min & 20,9 detik \\
& Max & 17,1 detik \\
\hline Ekstrakurikuler Bolabasket & $\mathrm{n}$ & 36 \\
& Mean & 19,03 detik \\
& SD & 1,03 detik \\
& Min & 21,1 detik \\
& Max & 17,0 detik \\
\hline
\end{tabular}

Keterangan :

$\mathrm{n} \quad$ = Banyaknya sampel pada setiap kelompok

Mean = Rata-rata skor tes Illinois

$\mathrm{SD} \quad=$ Standar deviasi atau simpangan baku

Min = Skor terkecil tes Illinois

Max = Skor terbesar tes Illinois

\subsubsection{Deskriptif Data Hasil Tes Kelincahan Gerak Peserta Ekstrakurikuler Futsal SMAN 4 Malang}

Berdasarkan data hasil tes kelincahan gerak peserta kegiatan ekstrakurikuler futsal SMAN 4 Malang dengan jumlah sampel penelitian sebanyak 35 peserta, diperoleh hasil ratarata tes 18,56 detik, sedangkan simpangan baku (Standar Deviasi) tes 0,86 detik, skor minimal tes 20,9 detik dan skor maksimal tes 17,1 detik. Maka, distribusi frekuensi dapat dijabarkan sebagai berikut.

Tabel 2. Distribusi Frekuensi Tes Kelincahan Gerak Peserta Kegiatan Ekstrakurikuler Futsal SMAN 4 Malang

\begin{tabular}{cccc}
\hline No & Rentangan Skor & $\begin{array}{c}\text { Frekuensi } \\
\text { Absolut }\end{array}$ & $\begin{array}{c}\text { Frekuensi } \\
\text { Relatif }\end{array}$ \\
\hline 1 & $17,1-17,7$ & 5 & 14,29 \\
2 & $17,8-18,4$ & 11 & 31,43
\end{tabular}


Sport Science and Health, 3(5), 2021, 307-319

\begin{tabular}{cccc}
\hline No & Rentangan Skor & $\begin{array}{c}\text { Frekuensi } \\
\text { Absolut }\end{array}$ & $\begin{array}{c}\text { Frekuensi } \\
\text { Relatif }\end{array}$ \\
\hline 3 & $18,5-19,1$ & 14 & 40 \\
4 & $19,2-19,8$ & 2 & 5,71 \\
5 & $19,9-20,5$ & 2 & 5,71 \\
6 & $20,6-21,2$ & 1 & 2,86 \\
\hline Jumlah & & 35 & 100 \\
\hline
\end{tabular}

Berdasarkan tabel di atas, maka dapat dilihat dari 35 peserta kegiatan ekstrakurikuler futsal SMAN 4 Malang yang melaksanakan Illinois Agility Run Test bahwa frekuensi tertinggi terdapat pada rentang skor 18,5 - 19,1 dengan jumlah frekuensi sebanyak 14 peserta, sedangkan frekuensi terendah terdapat pada rentang skor 20,6 - 21,2 dengan jumlah frekuensi sebanyak 1 peserta. Diagram batang untuk data Tabel 2 dapat dilihat pada gambar 1 sebagai berikut.

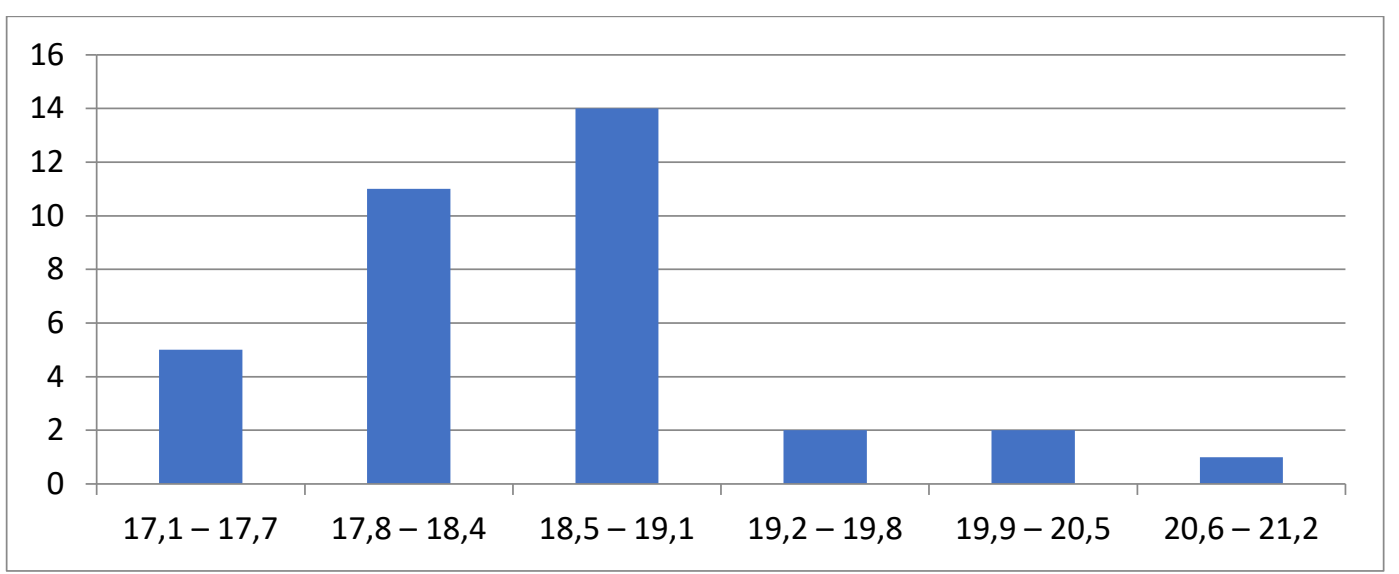

Gambar 1. Grafik Diagram Batang Tes Kelincahan Gerak Peserta Kegiatan Ekstrakurikuler Futsal SMAN 4 Malang

Berdasarkan data hasil tes kelincahan gerak peserta kegiatan ekstrakurikuler futsal SMAN 4 Malang, maka normatif persentase dan normatif tes Illinois peserta kegiatan ekstrakurikuler futsal putra SMAN 4 Malang dapat dijabarkan sebagai berikut.

Tabel 3 Normatif Persentase dan Normatif Tes Illinois Peserta Kegiatan Ekstrakurikuler Futsal Putra SMAN 4 Malang

\begin{tabular}{cccc}
\hline Rentangan Norma & Kategori & Frekuensi (F) & Persentase (\%) \\
\hline$<15,2$ & Sangat Baik & 0 & $0 \%$ \\
$15,2-16,1$ & Baik & 0 & $0 \%$ \\
$16,2-18,1$ & Cukup & 10 & $28,57 \%$ \\
$18,2-18,3$ & Buruk & 3 & $8,57 \%$ \\
$>18,3$ & Sangat Buruk & 22 & $62,86 \%$ \\
\hline Jumlah & & 35 & $100 \%$ \\
\hline
\end{tabular}

Berdasarkan Tabel 3 di atas, maka dapat dilihat persentase norma dari data hasil tes Illinois peserta kegiatan ekstrakurikuler futsal putra SMAN 4 Malang sebesar 28,57\% masuk ke dalam kategori cukup, 8,57\% masuk ke dalam kategori buruk, dan 62,86\% masuk ke dalam kategori sangat buruk. Sedangkan, untuk kategori baik dan sangat baik tidak ada satupun dari 
peserta kegiatan ekstrakurikuler futsal SMAN 4 Malang yang mampu meraihnya. Diagram batang untuk data Tabel 3 dapat dilihat pada gambar 2 sebagai berikut.

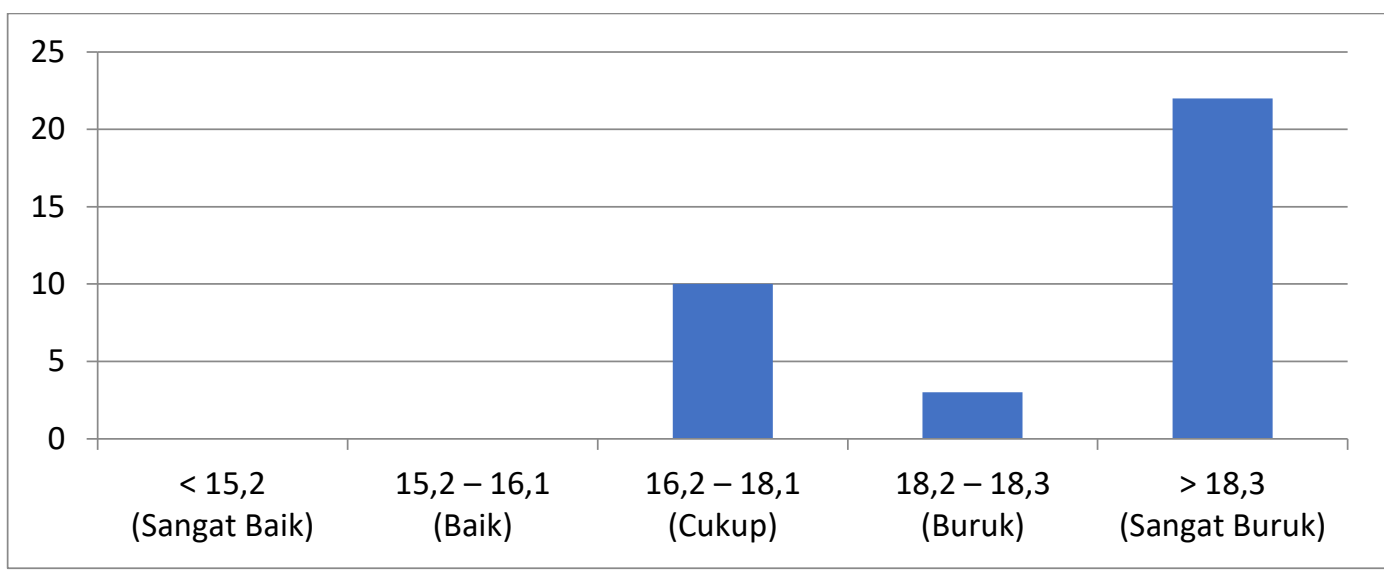

Gambar 2. Grafik Diagram Batang Normatif Tes Kelincahan Gerak Peserta Kegiatan Ekstrakurikuler Futsal SMAN 4 Malang

\subsubsection{Deskriptif Data Hasil Tes Kelincahan Gerak Peserta Ekstrakurikuler Bolabasket SMAN 4 Malang}

Berdasarkan data hasil tes kelincahan gerak peserta kegiatan ekstrakurikuler bolabasket SMAN 4 Malang dengan jumlah sampel penelitian sebanyak 36 peserta, diperoleh hasil rata-rata tes 19,03 detik, sedangkan simpangan baku (Standar Deviasi) tes 1,03 detik, skor minimal tes 21,1 detik dan skor maksimal tes 17,0 detik. Maka, distribusi frekuensi dapat dijabarkan sebagai berikut.

Tabel 4. Distribusi Frekuensi Tes Kelincahan Gerak Peserta Kegiatan Ekstrakurikuler Bolabasket SMAN 4 Malang

\begin{tabular}{cccc}
\hline No & Rentangan Skor & Frekuensi Absolut & Frekuensi Relatif \\
\hline 1 & $17,0-17,7$ & 5 & 13,89 \\
2 & $17,8-18,5$ & 7 & 19,44 \\
3 & $18,6-19,3$ & 6 & 16,67 \\
4 & $19,4-20,1$ & 13 & 36,11 \\
5 & $20,2-20,9$ & 4 & 11,11 \\
6 & $21,0-21,7$ & 1 & 2,78 \\
\hline Jumlah & & 36 & 100 \\
\hline
\end{tabular}

Berdasarkan tabel di atas, maka dapat dilihat dari 36 peserta kegiatan ekstrakurikuler bolabasket SMAN 4 Malang yang melaksanakan Illinois Agility Run Test bahwa frekuensi tertinggi terdapat pada rentang skor 19,4-20,1 dengan jumlah frekuensi sebanyak 13 peserta, sedangkan frekuensi terendah terdapat pada rentang skor 21,0 - 21,7 dengan jumlah frekuensi sebanyak 1 peserta. Diagram Batang untuk data Tabel 4 dapat dilihat pada gambar 3 sebagai berikut. 


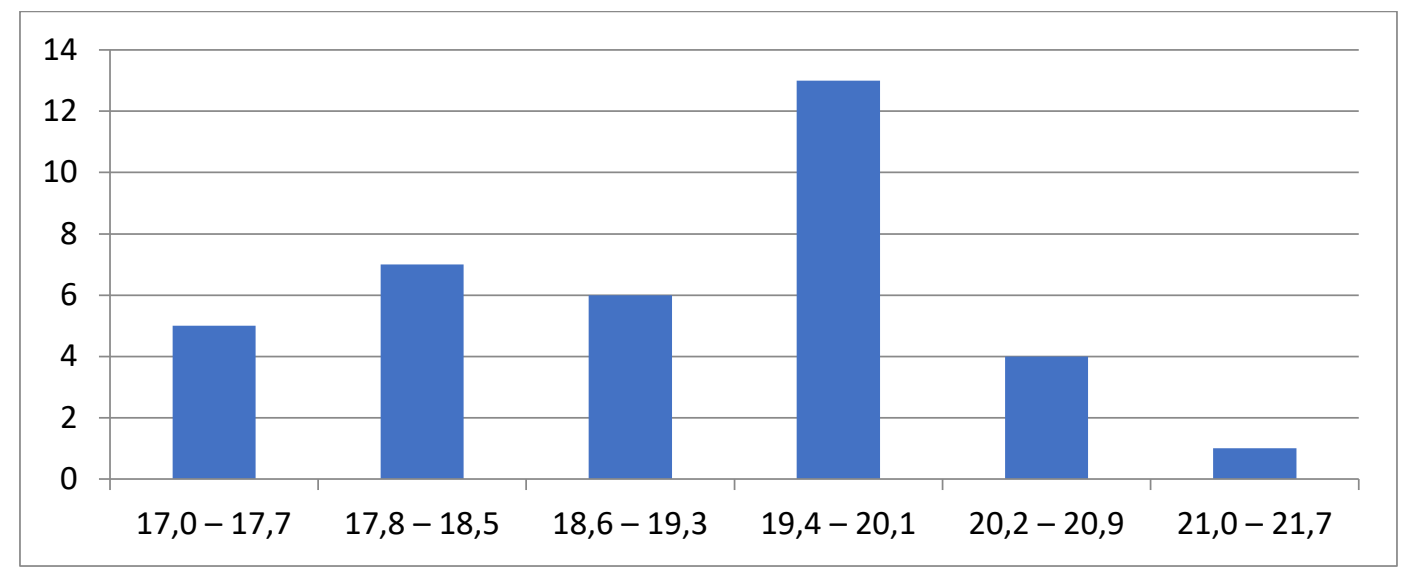

Gambar 3. Grafik Diagram Batang Tes Kelincahan Gerak Peserta Kegiatan Ekstrakurikuler Bolabasket SMAN 4 Malang

Berdasarkan data hasil tes kelincahan gerak peserta kegiatan ekstrakurikuler bolabasket SMAN 4 Malang, maka normatif persentase dan normatif tes Illinois peserta kegiatan ekstrakurikuler bolabasket putra SMAN 4 Malang dapat dijabarkan sebagai berikut.

Tabel 5. Normatif Persentase dan Normatif Tes Illinois Peserta Kegiatan Ekstrakurikuler Bolabasket Putra SMAN 4 Malang

\begin{tabular}{cccc}
\hline Rentangan Norma & Kategori & Frekuensi (F) & Persentase (\%) \\
\hline$<15,2$ & Sangat Baik & 0 & $0 \%$ \\
$15,2-16,1$ & Baik & 0 & $0 \%$ \\
$16,2-18,1$ & Cukup & 7 & $19,45 \%$ \\
$18,2-18,3$ & Buruk & 3 & $8,33 \%$ \\
$>18,3$ & Sangat Buruk & 26 & $72,22 \%$ \\
Jumlah & & 36 & $100 \%$ \\
\hline
\end{tabular}

Berdasarkan Tabel 5 di atas, maka dapat dilihat persentase norma dari data hasil tes Illinois peserta kegiatan ekstrakurikuler bolabasket putra SMAN 4 Malang sebesar 19,45\% masuk ke dalam kategori cukup, 8,33\% masuk ke dalam kategori buruk, dan 72,22\% masuk ke dalam kategori sangat buruk. Sedangkan, untuk kategori baik dan sangat baik tidak ada satupun dari peserta kegiatan ekstrakurikuler bolabasket SMAN 4 Malang yang mampu meraihnya. Diagram batang untuk data Tabel 5 dapat dilihat pada gambar 4 sebagai berikut. 


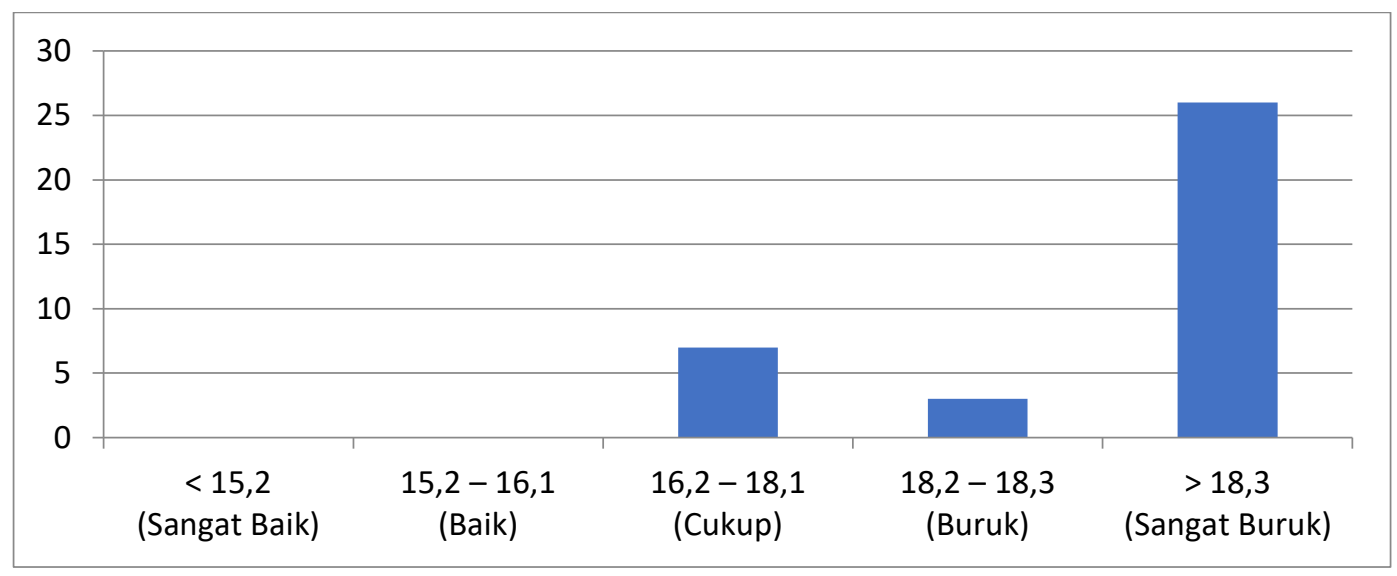

\section{Gambar 4. Grafik Diagram Batang Normatif Tes Kelincahan Gerak Peserta Kegiatan Ekstrakurikuler Bolabasket SMAN 4 Malang}

Hasil analisis data yang disajikan berupa: (1) hasil analisis uji prasyarat, yaitu uji normalitas menggunakan uji Kolmogorov-Smirnov dan uji homogenitas menggunakan uji F, (2) serta hasil uji hipotesis menggunakan uji T Sampel Bebas.

\subsubsection{Hasil Analisis Uji Prasyarat}

Pada analisis uji prasyarat ini dapat disajikan analisis data berupa (a) hasil uji normalitas dan (b) hasil uji homogenitas.

\subsubsection{Hasil Analisis Uji Normalitas}

Uji normalitas adalah sebuah cara untuk menetapkan apakah distribusi data dalam sampel yang diambil berasal dari populasi tertentu dengan distribusi normal atau tidak (Budiwanto, 2017:627). Uji normalitas dalam penelitian ini menggunakan uji KolmogorovSmirnov dengan taraf signifikansi $\alpha=0,05$. Uji normalitas digunakan untuk menguji skor tes kelincahan gerak yang telah dilakukan oleh masing-masing peserta kegiatan ekstrakurikuler futsal dan bolabasket SMAN 4 Malang berada pada distribusi normal atau tidak. Rangkuman hasil penghitungan uji normalitas ditunjukkan dalam tabel berikut ini.

Tabel 6. Hasil Analisis Uji Normalitas Kelincahan Gerak Peserta Kegiatan Ekstrakurikuler Futsal SMAN 4 Malang

\begin{tabular}{lcccl}
\hline \multicolumn{1}{c}{ Kelompok } & n & Dhitung $_{\text {hel }}$ & D tabel & \multicolumn{1}{c}{ Keterangan } \\
\hline $\begin{array}{l}\text { Peserta Kegiatan } \\
\text { Ekstrakurikuler Futsal }\end{array}$ & 35 & 0,115 & 0,230 & $\begin{array}{l}\text { Dhitung }<D_{\text {tabel. }} \alpha=0,05=\text { Data } \\
\text { berdistribusi normal }\end{array}$ \\
\hline
\end{tabular}

Berdasarkan hasil uji normalitas tes kelincahan gerak peserta kegiatan ekstrakurikuler futsal SMAN 4 Malang menggunakan Illinois Agility Run Test pada Tabel 4.4 di atas diperoleh hasil diperoleh hasil $D_{\text {hitung }} 0,115<D_{\text {tabel }} 0,230$ dengan taraf signifikansi $\alpha=0,05$. Hal ini berarti bahwa data kelincahan gerak peserta kegiatan ekstrakurikuler futsal SMAN 4 Malang menggunakan Illinois Agility Run Test berdistribusi normal, sehingga dapat dilanjutkan ke uji homogenitas. 
Tabel 7. Hasil Analisis Uji Normalitas Kelincahan Gerak Peserta Kegiatan Ekstrakurikuler Bolabasket SMAN 4 Malang

\begin{tabular}{lcccc}
\hline Kelompok & n & Dhitung $_{\text {hegel }}$ & D tabel & Keterangan \\
\hline $\begin{array}{l}\text { Peserta Kegiatan } \\
\text { Ekstrakurikuler Bolabasket }\end{array}$ & 36 & 0,146 & 0,230 & $\begin{array}{c}D_{\text {hitung }}<\mathrm{D}_{\text {tabel. }} \alpha=0,05= \\
\text { Data berdistribusi normal }\end{array}$ \\
\hline
\end{tabular}

Berdasarkan hasil uji normalitas tes kelincahan gerak peserta kegiatan ekstrakurikuler bolabasket SMAN 4 Malang menggunakan Illinois Agility Run Test pada Tabel di atas diperoleh hasil diperoleh hasil $D_{\text {hitung }} 0,146<D_{\text {tabel }} 0,230$ dengan taraf signifikansi $\alpha=0,05$. Hal ini berarti bahwa data kelincahan gerak peserta kegiatan ekstrakurikuler bolabasket SMAN 4 Malang menggunakan Illinois Agility Run Test berdistribusi normal, sehingga dapat dilanjutkan ke uji homogenitas.

\subsubsection{Hasil Analisis Uji Homogenitas}

Uji homogenitas dilakukan terhadap data skor keseluruhan tes kelincahan gerak peserta kegiatan ekstrakurikuler futsal dan bolabasket SMAN 4 Malang menggunakan uji F pada taraf signifikansi $\alpha=0,05$. Hasil penghitungan lengkap uji homogenitas dapat dilihat pada lembar lampiran. Di bawah ini disajikan rangkuman hasil penghitungan uji homogenitas dalam Tabel 4.6 sebagai berikut.

Tabel 8. Hasil Analisis Uji Homogenitas Kelincahan Gerak Peserta Kegiatan Ekstrakurikuler Futsal dan Bolabasket SMAN 4 Malang

\begin{tabular}{|c|c|c|c|c|}
\hline Kelompok & $\mathbf{S}^{2}$ & F $_{\text {hitung }}$ & $F_{\text {tabel }}$ & Keterangan \\
\hline Ekstrakurikuler Futsal & 0,74 & & & \\
\hline $\begin{array}{l}\text { Ekstrakurikuler } \\
\text { Bolabasket }\end{array}$ & 1,07 & 0,69 & 1,72 & 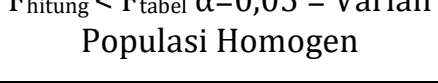 \\
\hline
\end{tabular}

Berdasarkan hasil analisis uji homogenitas menggunakan uji F yang telah disajikan pada Tabel di atas diperoleh hasil $\mathrm{F}_{\text {hitung }} 0,69<\mathrm{F}_{\text {tabel }}$ 1,72. Dengan demikian, dapat disimpulkan bahwa data hasil tes kelincahan gerak peserta kegiatan ekstrakurikuler futsal dan bolabasket SMAN 4 Malang menunjukkan varian populasi yang homogen.

\subsubsection{Hasil Analisis Uji Hipotesis}

Setelah dilakukan uji prasyarat yaitu uji normalitas dan uji homogenitas dan didapatkan hasil bahwa seluruh kelompok sampel berasal dari populasi yang berdistribusi normal dan homogen, selanjutnya akan dilakukan pengujian terhadap hipotesis dengan menggunakan uji T Sampel Bebas. Di bawah ini disajikan rangkuman hasil penghitungan uji T Sampel Bebas dalam Tabel sebagai berikut.

Tabel 9. Hasil Analisis Uji T Sampel Bebas Kelincahan Gerak Peserta Kegiatan Ekstrakurikuler Futsal dan Bolabasket SMAN 4 Malang

\begin{tabular}{lcccccc}
\hline \multicolumn{1}{c}{ Kelompok } & $\mathbf{n}$ & $\overline{\mathbf{X}}$ & $\mathbf{S}^{\mathbf{2}}$ & $\mathbf{T}_{\text {hitung }}$ & $\mathbf{T}_{\text {tabel }}$ & Keterangan \\
\hline $\begin{array}{l}\text { Ekstrakurikuler } \\
\text { Futsal }\end{array}$ & 35 & 18,56 & 0,74 & $-2,08$ & 1,67 & $\begin{array}{c}\text { Thitung }>\text { T tabel } \alpha=0,05= \\
\text { Ada perbedaan }\end{array}$ \\
\cline { 6 - 6 }
\end{tabular}




\begin{tabular}{lcccccc}
\hline Kelompok & $\mathbf{n}$ & $\overline{\mathbf{X}}$ & $\mathbf{S}^{\mathbf{2}}$ & $\mathbf{T}_{\text {hitung }}$ & $\mathbf{T}_{\text {tabel }}$ & Keterangan \\
\hline $\begin{array}{l}\text { Ekstrakurikuler } \\
\text { Bolabasket }\end{array}$ & 36 & 19,03 & 1,07 & & & \\
\hline
\end{tabular}

Berdasarkan hasil analisis data uji T Sampel Bebas kelincahan gerak pada peserta kegiatan ekstrakurikuler futsal yang berjumlah 35 peserta dan peserta kegiatan ekstrakurikuler bolabasket yang berjumlah 36 peserta menggunakan Illinois Agility Run Test diperoleh hasil $\mathrm{T}_{\text {hitung }}>\mathrm{T}_{\text {tabel }}=\mathrm{T}_{(0,05: 69)}=-2,08>1,67$ dengan taraf signifikansi $\alpha=0,05$. Dengan demikian, dapat disimpulkan bahwa $\mathrm{H}_{0}$ ditolak dan $\mathrm{H}_{\mathrm{a}}$ diterima. Artinya, ada perbedaan yang signifikan kemampuan kelincahan gerak antara peserta kegiatan ekstrakurikuler futsal dengan peserta kegiatan ekstrakurikuler bolabasket di SMAN 4 Malang.

\subsection{Pembahasan}

Berdasarkan hasil uji hipotesis menggunakan uji T Sampel Bebas pada data skor prestasi tes kelincahan gerak peserta kegiatan ekstrakurikuler futsal dan bolabasket SMAN 4 Malang diperoleh hasil $\mathrm{T}_{\text {hitung }}-2,08>\mathrm{T}_{\text {tabel }} 1,67$ dengan taraf signifikansi $\alpha=0,05$. Hal ini berarti bahwa ada perbedaan yang signifikan kemampuan kelincahan gerak antara peserta kegiatan ekstrakurikuler futsal dengan peserta kegiatan ekstrakurikuler bolabasket di SMAN 4 Malang. Adapun hasil rata-rata hitung untuk peserta kegiatan ekstrakurikuler futsal SMAN 4 Malang adalah 18,56 detik, sedangkan hasil rata-rata hitung untuk peserta kegiatan ekstrakurikuler bolabasket SMAN 4 Malang adalah 19,03 detik. Dari paparan hasil rata-rata hitung antara peserta kegiatan ekstrakurikuler futsal dan bolabasket SMAN 4 Malang dapat diketahui bahwa peserta kegiatan ekstrakurikuler futsal memiliki kemampuan kelincahan gerak yang lebih baik dari peserta kegiatan ekstrakurikuler bolabasket. Berdasarkan rekap hasil tes kelincahan gerak, sebanyak 19 peserta memperoleh skor di atas rata-rata dari jumlah 35 peserta kegiatan ekstrakurikuler futsal, sedangkan dari jumlah 36 peserta kegiatan ekstrakurikuler basket, sebanyak 14 peserta memperoleh skor di atas rata-rata. Hal ini menunjukkan bahwa lebih dari $50 \%$ peserta kegiatan ekstrakurikuler bolabasket memperoleh skor di bawah rata-rata.

Adapun persentase norma dari data hasil tes Illinois peserta kegiatan ekstrakurikuler futsal putra SMAN 4 Malang sebesar 28,57\% masuk ke dalam kategori cukup, 8,57\% masuk ke dalam kategori buruk, dan 62,86\% masuk ke dalam kategori sangat buruk. Sedangkan, untuk kategori baik dan sangat baik tidak ada satupun dari peserta kegiatan ekstrakurikuler futsal SMAN 4 Malang yang mampu meraihnya. Di sisi lain, persentase norma dari data hasil tes Illinois peserta kegiatan ekstrakurikuler bolabasket putra SMAN 4 Malang sebesar 19,45\% masuk ke dalam kategori cukup, 8,33\% masuk ke dalam kategori buruk, dan 72,22\% masuk ke dalam kategori sangat buruk. Sedangkan, untuk kategori baik dan sangat baik tidak ada satupun dari peserta kegiatan ekstrakurikuler bolabasket SMAN 4 Malang yang mampu meraihnya. Itu artinya, sebanyak $100 \%$ dari peserta kegiatan ekstrakurikuler futsal dan bolabasket berada pada kategori cukup hingga sangat buruk. Kondisi kelincahan gerak peserta kegiatan ekstrakurikuler tersebut dipengaruhi oleh dua faktor, yaitu faktor internal dan faktor eksternal. Faktor internal yang mempengaruhi adalah motivasi dan kemampuan peserta kegiatan itu sendiri. Hampir seluruh peserta kegiatan memilih kegiatan ekstrakurikuler futsal dan bolabasket sebagai pilihannya berdasarkan kemauannya sendiri. Tetapi, untuk kemampuan kondisi fisik dan keterampilan bermain masih di bawah rata-rata, karena relatif banyak dari peserta kegiatannya yang hanya mengikuti latihan di sekolah saja sesuai jadwal 
latihan kegiatan ekstrakurikulernya. Sedangkan, faktor eksternal yang mempengaruhi antara lain faktor pelatih, program latihan, hingga sarana dan prasarana.

Kegiatan ekstrakurikuler futsal di SMAN 4 Malang dilaksanakan dua kali dalam satu minggu. Latihan dimulai pada pukul 15.30 WIB hingga pukul 17.30 WIB. Sarana dan prasarana yang digunakan untuk latihan cukup memadai, mulai dari lapangan, bola, cone, hingga 2 gawang telah tersedia meskipun dengan kualitas yang kurang standar. Sedangkan, kegiatan ekstrakurikuler bolabasket di SMAN 4 Malang dilaksanakan dua kali dalam satu minggu. Jadwal latihan berlangsung selama 2 jam, dimulai pada pukul 15.30 WIB dan diakhiri pada pukul 17.30 WIB. Sarana dan prasarana yang digunakan untuk latihan kurang memadai. Salah satu ring basket di lapangan dalam kondisi rusak, sehingga hanya terdapat satu ring basket yang dapat digunakan. Untuk fasilitas yang lain berupa lapangan, bola, dan cone telah tersedia dengan kualitas yang kurang standar.

Ruslan (2011) menjelaskan faktor-faktor yang mempengaruhi kondisi fisik antara lain faktor latihan, faktor istirahat, faktor kebiasaan hidup sehat, lingkungan serta makanan dan gizi. Berdasarkan paparan di atas dan didukung dengan hasil angket analisis kebutuhan (need assessment) yang dibagikan kepada peserta kegiatan ekstrakurikuler futsal dan bolabasket SMAN 4 Malang, ada beberapa faktor yang mempengaruhi kemampuan kelincahan gerak peserta kegiatan ekstrakurikuler futsal lebih baik dibandingkan dengan peserta kegiatan ekstrakurikuler bolabasket di SMAN 4 Malang, diantaranya (1) jadwal latihan lebih terstruktur, (2) program latihan lebih tersusun dengan baik, (3) fasilitas lebih memadai, (4) dan banyak dari peserta kegiatan ekstrakurikulernya yang mengikuti latihan tambahan di luar kegiatan ekstrakurikuler. Selain itu, faktor jadwal latihan juga dapat mempengaruhi adanya perbedaan kemampuan kelincahan gerak. Jadwal latihan kegiatan ekstrakurikuler bolabasket yang terletak pada hari Sabtu dan Minggu dirasa tidak efektif untuk berlatih, karena pada akhir pekan tersebut banyak dari peserta kegiatannya yang seringkali tidak hadir latihan dengan alasan yang beragam. Hal ini tentu tidak menerapkan prinsip latihan yaitu partisipasi aktif. Berbeda dengan peserta kegiatan ekstrakurikuler futsal yang berlatih pada hari efektif yaitu Rabu dan Jumat, sehingga lebih banyak dari peserta kegiatannya yang hadir latihan. Sehingga, pada akhirnya kemampuan kondisi fisik kelincahan gerak peserta kegiatan ekstrakurikuler futsal lebih baik dari peserta kegiatan ekstrakurikuler bolabasket.

Berdasarkan hasil penelitian yang telah dilakukan oleh peneliti, dapat disimpulkan bahwa ada perbedaan kemampuan kelincahan gerak antara peserta kegiatan ekstrakurikuler futsal dengan peserta kegiatan ekstrakurikuler bolabasket di SMAN 4 Malang. Pemberian latihan kondisi fisik yang terstruktur serta menerapkan prinsip pengulangan dan beban berlebih kepada peserta kegiatan ekstrakurikuler, maka akan memberikan peningkatan terhadap kemampuan kondisi fisik khususnya dalam unsur kelincahan gerak.

\section{Simpulan}

Berdasar pada pengujian hipotesis dan pembahasan dalam penelitian yang telah dilakukan, maka diperoleh hasil penelitian yang dapat disimpulkan bahwa ada perbedaan yang signifikan kemampuan kondisi fisik unsur kelincahan gerak antara peserta kegiatan ekstrakurikuler futsal dengan peserta kegiatan ekstrakurikuler bolabasket di SMAN 4 Malang. 


\section{Daftar Rujukan}

Adam, Q. H. (2015). Faktor Biomotor dan Psikomotor Penentu Keterampilan Futsal (Analisis Faktor Dominan Penentu Keterampilan Futsal pada Atlet Futsal di Jawa Tengah). Skripsi. Surakarta: Universitas Sebelas Maret.

Amiq, F. (2014). Futsal (Sejarah, Teknik Dasar, Persiapan Fisik, Strategi, dan Peraturan Permainan). Malang: Universitas Negeri Malang.

Arthawan, M. F. (2016). Pengaruh Latihan Hexagon dan Zig-Zag Run terhadap Kelincahan Peserta Ekstrakurikuler Futsal SMP Laboratorium Universitas Negeri Malang. Skripsi. Malang: Universitas Negeri Malang.

Budiwanto, S. (2017). Metodologi Penelitian Dalam Keolahragaan. Malang: Universitas Negeri Malang (UM Press).

Hamid, H. M. A., Heryanto, N., Kartono, \& Suwarno. (2017). Statistika Pendidikan. Jakarta: Universitas Terbuka.

Hidayah, M. R., \& Wirawan, O. (2019). Perbandingan Kondisi Fisik Ekstrakurikuler Bola Basket Putra Di SMAN Pacet Kabupaten Mojokerto dan SMAN 1 Kota Mojokerto Ditinjau Dari Prestasi Yang Diraih. Jurnal Prestasi Olahraga, 1(2), 1-9.

Homoud, M. N. A. (2015). Relationships Between Illinois Agility Test And Reaction Time In Male Athletes. The Swedish Journal of Scientific Research, 2(3), 28-33.

Milanović, Z., Sporiš, G., Trajković, N., \& Fiorentini, F. (2011). Differences in Agility Performance Between Futsal and Soccer Players. Sport Science, 4(2), 55-59.

Nurrochmah, S. (2016). Tes dan Pengukuran dalam Pendidikan Jasmani \& Keolahragaan. Malang: Universitas Negeri Malang (UM Press).

Ruslan. (2011). Meningkatkan Kondisi Fisik Atlet Pusat Pendidikan dan Latihan Olahraga Pelajar (PPLP) di Provinsi Kalimantan Timur. Jurnal ILARA, 11(2), 45-56.

Siregar, S. (2015). Statistika Terapan Untuk Perguruan Tinggi. Jakarta: Prenadamedia Group.

Suliyanto. (2014). Statistika Non Parametrik. Yogyakarta: CV. Andi Offset

Winarno, M. E. (2013). Metodologi Penelitian Dalam Pendidikan Jasmani. Malang: UM Press. 